\title{
Correspondence
}

\section{Voluntary Euthanasia Society}

SIR

Though Barbara Smoker of the Voluntary Euthanasia Society (Exit) may make soothing sounds (in JME vol 9, p 52) to try to reassure us that her society only believes in legalising the killing of people who have degenerative illnesses 'with adequate safeguards', one is bound to observe that actions speak louder than words.

The last secretary of her organisation went to prison for taking the law into his own hands and assisting people to commit suicide. One of the people his accomplice visited had to throw him out because she no longer felt suicidal. Miss
Smoker was quoted by the Daily Telegraph as saying no stigma attached to the secretary as a result of the trial.

The euthanasia society also published a booklet to help people to commit suicide which has already been found beside a 22-year-old depressive who killed himself in Claridges. He had no degenerative illness.

Recently we have heard of the suicide pact involving another of the society's officers - Arthur Koestler. I can only feel compassion for his plight. But we should not lose sight of the other partner in the pact - his wife - a relatively healthy woman two decades his junior, whose only apparent reason to want death was her fear of bereavement.

In spite of blandishments, one can only conclude that the Voluntary Euth- anasia Society is a dangerous organisation whose leaders sometimes slide down their own slippery slope. Their actions seem to betray far more horrific aims than their calculated public statements suggest.

Death is not the solution to all human problems that these organisations seem to believe. It is because there are other more positive responses to distress that we who work in hospices, as Miss Smoker observed, continue to oppose euthanasia.

RICHARD LAMERTON
New Age Hospice
7 Chelsea Place
Houston
Texas 77006

\section{News and notes}

\section{Health care and the humanities}

The Association for Faculty in the Medical Humanities, a section of the Society for Health and Human Values, is planning a conference to be held during the annual meeting of the Association for American Medical Colleges, November 5-7, 1983, in Washington DC. Papers with a maximum reading time of 20 minutes on any topic relating health care and traditional concerns of the humanities will be considered. The papers will receive blind review, so the author's name should appear only on a cover page. The deadline for receipt of essays is July 1, 1983. Five copies should be sent to Peter C Williams, JD, $\mathrm{PhD}$, Department of Community and Preventive Medicine, Health Sciences Center, Stony Brook, NY, 11794. 